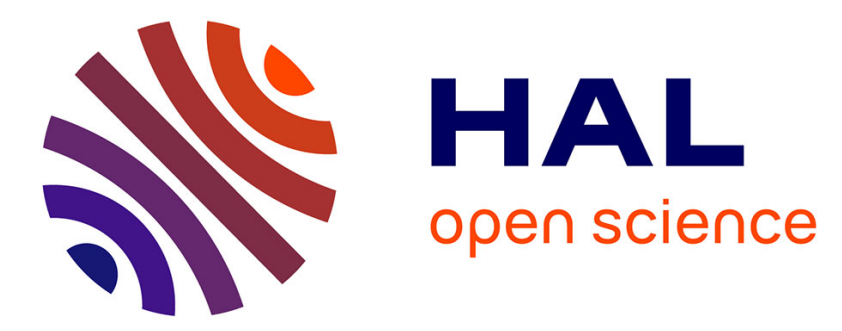

\title{
Accounting for rainfall systematic spatial variability in flash flood forecasting
}

\author{
Audrey Douinot, Hélène Roux, Pierre-André Garambois, Kévin Larnier, \\ David Labat, Denis Dartus
}

\section{- To cite this version:}

Audrey Douinot, Hélène Roux, Pierre-André Garambois, Kévin Larnier, David Labat, et al.. Accounting for rainfall systematic spatial variability in flash flood forecasting. Journal of Hydrology, 2016, vol. 541 (Part A), pp. 359-370. 10.1016/j.jhydrol.2015.08.024 . hal-01440217

\section{HAL Id: hal-01440217 https://hal.science/hal-01440217}

Submitted on 19 Jan 2017

HAL is a multi-disciplinary open access archive for the deposit and dissemination of scientific research documents, whether they are published or not. The documents may come from teaching and research institutions in France or abroad, or from public or private research centers.
L'archive ouverte pluridisciplinaire HAL, est destinée au dépôt et à la diffusion de documents scientifiques de niveau recherche, publiés ou non, émanant des établissements d'enseignement et de recherche français ou étrangers, des laboratoires publics ou privés. 


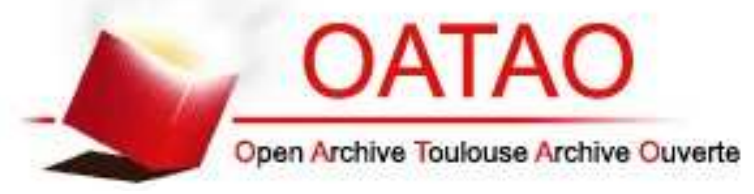

\section{Open Archive TOULOUSE Archive Ouverte (OATAO)}

OATAO is an open access repository that collects the work of Toulouse researchers and makes it freely available over the web where possible.

This is an author-deposited version published in : http://oatao.univ-toulouse.fr/ Eprints ID : 17444

To link to this article : DOI : $10.1016 / \mathrm{j} . j h y d r o l .2015 .08 .024$

URL : http://dx.doi.org/10.1016/j.jhydrol.2015.08.024

To cite this version : Douinot, Audrey and Roux, Hélène and

Garambois, Pierre-André and Larnier, Kévin and Labat, David and

Dartus, Denis Accounting for rainfall systematic spatial variability

in flash flood forecasting. (2016) Journal of Hydrology, vol. 541

(Part A). pp. 359-370. ISSN 0022-1694

Any correspondence concerning this service should be sent to the repository administrator: staff-oatao@ listes-diff.inp-toulouse.fr 


\title{
Accounting for rainfall systematic spatial variability in flash flood forecasting
}

\author{
Audrey Douinot ${ }^{\mathrm{a}, \mathrm{b}, *}$, Hélène Roux ${ }^{\mathrm{a}, \mathrm{b}}$, Pierre-André Garambois ${ }^{\mathrm{a}, \mathrm{b}}$, Kévin Larnier ${ }^{\mathrm{a}, \mathrm{b}}$, David Labat ${ }^{\mathrm{c}}$, \\ Denis Dartus $\mathrm{a}, \mathrm{b}$
}

${ }^{a}$ University of Toulouse, INPT, UPS, IMFT (Institut de Mécanique des Fluides de Toulouse), Allée Camille Soula, 31400 Toulouse, France

${ }^{\mathrm{b}}$ CNRS, IMFT, 31400 Toulouse, France

${ }^{\mathrm{C}}$ University of Toulouse, CNRS, Géosciences Environnement Toulouse, IRD, OMP, Toulouse, France

Keywords:

Flash flood

Rainfall spatial variability

Flash flood guidance

Hydrological response

Physical based model

\section{S U M M A R Y}

Just as with the storms that cause them, flash floods are highly variable and non-linear phenomena in both time and space; hence understanding and anticipating the genesis of flash floods is far from straightforward. There is therefore a huge requirement for tools with the potential to provide advance warning of situations likely to lead to flash floods, and thus provide additional time for the flood forecasting services. The Flash Flood Guidance (FFG) method is used on US catchments to estimate the average number of inches of rainfall for given durations required to produce flash flooding. This rainfall amount is used afterwards as a flood warning threshold. In Europe, flash floods often occur on small catchments (approximately $100 \mathrm{~km}^{2}$ ) and it has already been shown that the spatial variability of rainfall has a great impact on the catchment response (Le Lay and Saulnier, 2007). Therefore, in this study, an improved FFG method which accounts for rainfall spatial variability is proposed. The objectives of this paper are (i) to assess the FFG method applicability on French Mediterranean catchments with a distributed processoriented hydrological model and (ii) to assess the effect of the rainfall spatial variability on this method. The results confirm the influence of the spatial variability of rainfall events in relation with its interaction with soil properties.

\section{Introduction}

The term "flash flood" refers to sudden floods having high peak discharges in a short response time. They result from a combination of meteorological and hydrological factors (Gaume et al., 2009). Intense storm events delivering high amounts of rain water appear to be the first condition for flash flooding to be initiated. Watershed characteristics such as small catchments $\left(<500 \mathrm{~km}^{2}\right)$ or steep slopes $\left(>0.02 \mathrm{~m} \mathrm{~m}^{-1}\right)$ are associated with short and rapid flood response. Poor infiltration capacities emphasise the response magnitude. Flash floods therefore occur mostly in the head watersheds of the Mediterranean climatic zone or within inland continental Europe (Marchi et al., 2010) and in the autumn season where intense storm events appear and saturated soils restrict the amount of infiltration.

Since the hydrological responses are rapid and extreme, flash flood events are destructive (Roux et al., 2011). Weather-driven

\footnotetext{
* Corresponding author at: University of Toulouse, INPT, UPS, IMFT (Institut de Mécanique des Fluides de Toulouse), Allée Camille Soula, 31400 Toulouse, France. E-mail address: audrey.douinot@imft.fr (A. Douinot).
}

natural hazards represent the main natural disasters (Gaume et al., 2009). Among them, flash flood events are the most significant when life and economic damage are considered. For instance, a flash flood in France on June 6th, 2013 caused two victims and a total estimated damage of $\$ 655$ million (CKAN, 2013). More recently, storms that occurred in the Gard (Cévennes) region in October 2014 caused flooding of historic proportions in a large urban area including Montpellier (pop. 250,000).

In this context, flash flood forecasting is valuable, but its realization still remains a hard task. The main difficulties lie in flash flood timescales (Norbiato et al., 2008). The rapidity of the hydrological responses (from a few hours to one day) reduces the forecast time. Short lead times often prevent real-time observed discharge and rainfall data from being accurately assimilated. Forecasting methods should be achieved over small scales in both space and time. At the same time, easily observed (or predicted) data should be chosen to make forecasts as early as possible with the available data.

Several accepted methods for predicting flash floods are currently in use, which rely on the national forecasting service. In France, the ALHTAIR model (Bressand, 2002) is used in real time 
in the Gard region. It consists in a distributed conceptual model with a Horton-type production function and a geomorphological transfer function (Ayral et al., 2005). Spatial data such as soil infiltration capacity or rainfall forcing provide local forecasts. However, this conceptual model could not be used without calibration and the uncertainty in parameters on ungauged catchments remains open.

Another more widespread forecasting method is the Flash Flood Guidance (FFG) method (Mogil et al., 1978). FFG is defined as "the threshold rainfall [L] over accumulation periods of 1,3 and 6 hours required to initiate flooding on small streams that respond to rainfall within a few hours" (Georgakakos, 1986; Sweeney, 1992).

Several research projects have studied the applicability of the FFG method not only in the United States but also over the south-western Mediterranean arc (Carpenter et al., 1999; Ntelekos et al., 2006; Norbiato et al., 2008). Global conceptual models are used to calculate the threshold intensity. In particular, Norbiato et al. (2008) have demonstrated encouraging results for warning forecasts. They also conclude that the assumption of uniform forcing in space and time has a limited effect on the FFG method.

In contrast, however, other articles highlight the importance of spatial forcing variability in generating flash floods (Arnaud et al., 1999; Le Lay and Saulnier, 2007; Tramblay et al., 2010; Lobligeois, 2014; Morin and Yakir, 2014). Distributed hydrological models show significant improvements after including the local aspect of precipitation (Michaud and Sorooshian, 1994; Zoccatelli et al., 2010); and in particular, an increase in the likelihood criterion (Nash-Sutcliffe) of up to 30\% (Zoccatelli et al., 2010). Studying the particular case of the flash-flood event of 8-9 September 2002 in the Gard region, Anquetin et al. (2010) and Delrieu et al. (2005) found that the distribution of the spatial forcing particularly influences the flood dynamic when it interacts with the spatial distribution of the soil properties before saturation.

Incorporating the judicious inclusion of spatial information, a new method for forecasting flash flooding, named Spatialized Flash Flood Guidance Method (SFFG) is proposed. The objective is to improve the performance of the current FFG method while retaining its operational simplicity. One of the novel features of the study is the use of a physically based distributed hydrological model to implement these FFG and SFFG methods.

The article is in four parts: Section 2 will present the MARINE distributed model used for applying the FFG and SFFG methods. The characteristics of the three catchments being considered and those of the hydrometeorological database will be covered in Section 3. Section 4 will cover application of the FFG method. Finally, Section 5 will be dedicated to the presentation of the new SFFG method and its application.

\section{The MARINE model}

MARINE (Modélisation de l'Anticipation du Ruissellement et des Inondations pour des évéNements Extrêmes) is a distributed hydrological model developed specially for flash flood simulation. Based on physical processes, the main flash flood processes (infiltration, overland flow, channel routing) are detailed therein. On the other hand, low rate flow processes such as evapotranspiration, or baseflow are neglected. Fig. 1 details the model structure. More information is given by Roux et al. (2011).

MARINE is structured into three main modules. The first module allows separating surface runoff and infiltration with the Green-Ampt model. The second module represents subsurface downhill flow, and is driven by the TOPMODEL Darcy law adjustment (Beven and Kirkby, 1979). Finally the third module represents overland and channel flows. Rainfall excess is transferred to the catchment outlet in accordance with the Saint-Venant equations with kinematic wave assumption. The MARINE model requires DEM, soil and landcover data to run the simulation.

The MARINE simulation requires the calibration of five physical parameters: soil depth $C_{z}$, lateral hydraulic conductivity $C_{T_{0}}$, saturated hydraulic conductivity $C_{k}$, and the flood plain and riverbed Manning roughness coefficients, $n_{p}$ and $n_{r}$ respectively. $C_{z}, C_{T_{0}}$ and $C_{k}$ are multiplicative constants of the corresponding spatialised parameters $z, T_{0}$ and $K$ (cf. Fig. 1). In previous work the MARINE model was successfully calibrated to simulate more than 150 flash floods over twenty Mediterranean catchments (Garambois et al., 2015a,b). Sensitivity analysis using variancebased methods (Garambois et al., 2013) revealed in particular the

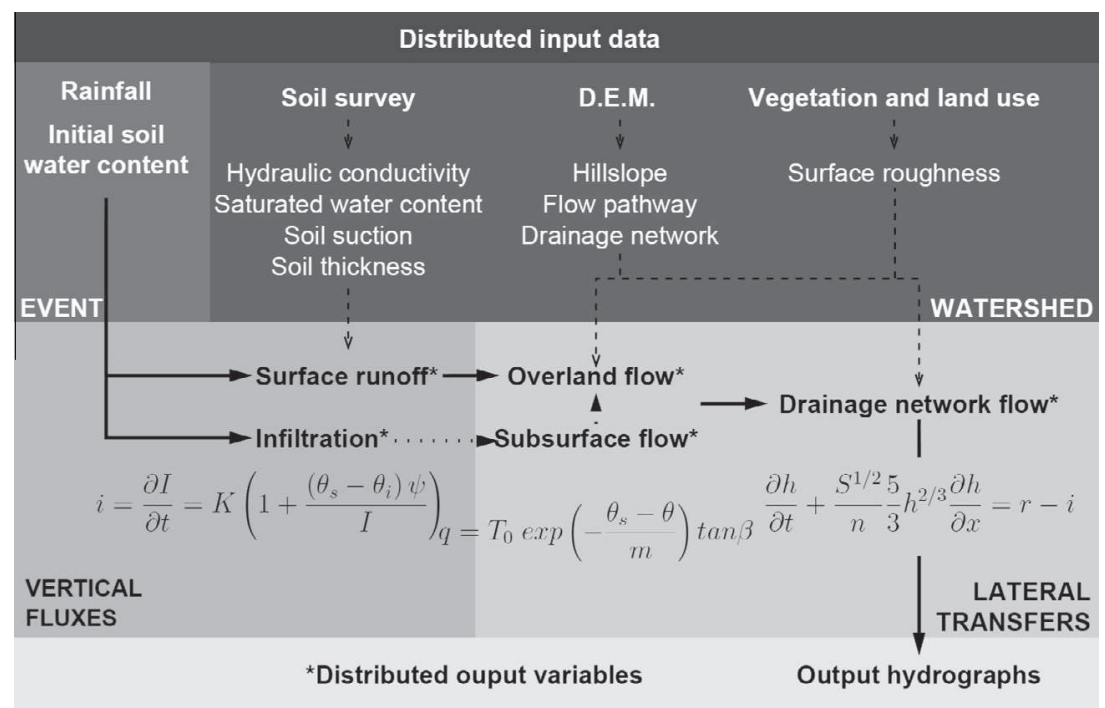

Fig. 1. MARINE model structure, parameters and variables (Roux et al., 2011). Green and Ampt infiltration equation: infiltration rate $i$ ( $\mathrm{m} \mathrm{s}{ }^{-1}$ ), cumulative infiltration $I$ (mm), saturated hydraulic conductivity $K\left(\mathrm{~m} \mathrm{~s}^{-1}\right)$, soil suction at wetting front $\psi(\mathrm{m})$, saturated and initial water contents are respectively $\theta_{\mathrm{s}}$ and $\theta_{i}\left(\mathrm{~m}^{3} \mathrm{~m}^{-3}\right)$. Subsurface flow: local transmissivity of fully saturated soil $T_{0}\left(\mathrm{~m}^{2} \mathrm{~s}^{-1}\right)$, saturated and local water contents are $\theta_{\mathrm{s}}$ and $\theta\left(\mathrm{m}^{3} \mathrm{~m}^{-3}\right)$, transmissivity decay parameter is $m(-)$, local slope angle $\beta$ (rad). Kinematic wave: water depth $h(\mathrm{~m})$, time $t(\mathrm{~s})$, overland flow velocity $u\left(\mathrm{~m} \mathrm{~s}^{-1}\right)$, space variable $x(\mathrm{~m})$, rainfall rate $r\left(\mathrm{~m} \mathrm{~s}^{-1}\right)$, infiltration rate $i\left(\mathrm{~m} \mathrm{~s}^{-1}\right)$, bed slope $S\left(\mathrm{~m} \mathrm{~m}^{-1}\right)$, Manning roughness coefficient $n\left(\mathrm{~m}^{-1 / 3} \mathrm{~s}\right)$. 
prior importance of parameterising soil depth for flash flood forecasting.

\section{Hydrological data and studied catchments}

\subsection{Study area}

The investigation focuses on the hydrological response of three catchments: the Beaume at Rosières $\left(195 \mathrm{~km}^{2}\right)$; the Ardèche at Vogüe $\left(622 \mathrm{~km}^{2}\right)$ and the Gardon at Anduze $\left(543 \mathrm{~km}^{2}\right)$. These three catchments are in the Cévennes-Vivarais region (Fig. 2), an area of highly contrasted hydrological regimes. Table 1 lists some of the geomorphological features of the catchments. Each has a marked topography with slope ratios greater than 0.02 , and they lie mainly on granite and/or shale bedrock. In particular, the upper part of the catchment area of the Gardon includes a karstic zone. The catchments in this study are essentially uninhabited with practically no hydraulic infrastructure.

These catchments were chosen primarily on the basis of an extensive set of hydrological and meteorological data for flash floods. In addition, the MARINE model (see Section 2), used for the remainder of the study, has already been implemented on these catchments with satisfactory results (Garambois et al., 2013, Tables 2-4).

\subsection{Hydrological data}

The performance of the FFG and SFFG methods in predicting flash floods is assessed by applying them to events observed over the last two decades in the three catchment areas. In all, 27 rainfall events leading to flash flood have been detected and will be used as the basis for the investigation (Tables 2-4). Pluviometric data are taken from the ARAMIS radar network (Météo France, Tabary, 2007) which, since 1994, has been providing rainfall data for the Mediterranean region over 5 min intervals with a spatial resolution of $1 \mathrm{~km} \times 1 \mathrm{~km}$. The flood forecasting services use the CALAMAR software to produce the rainfall depth by combining these radar data with raingauges data.
Table 1

Catchment characteristics.

\begin{tabular}{llllll}
\hline Catchment & $\begin{array}{l}\text { Station } \\
\text { name }\end{array}$ & $\begin{array}{l}\text { Area } \\
\left(\mathrm{km}^{2}\right)\end{array}$ & $\begin{array}{l}\text { Slope } \\
\text { ratio } \\
\left(\mathrm{m} \mathrm{m}^{-1}\right)\end{array}$ & $\begin{array}{l}\text { Mean annual } \\
\text { runoff } \\
\left(\mathrm{m}^{3} \mathrm{~s}^{-1}\right)\end{array}$ & $\begin{array}{l}2 \text { year return } \\
\text { time flow } \\
\left(\mathrm{m}^{3} \mathrm{~s}^{-1}\right)\end{array}$ \\
\hline Beaume & Rosières & 195 & 0.047 & 8.0 & 75 \\
Gardon & Anduze & 543 & 0.024 & 13.9 & 420 \\
Ardèche & Vogüe & 622 & 0.026 & 26.2 & 105 \\
\hline
\end{tabular}

a Max-min elevation divided by the longest flow path.

Apart from the events of 05/05/2010, 14/03/2002 and $18 / 04 / 2008$, the cumulative rainfall amounts recorded for the region are very high, greater than $100 \mathrm{~mm}$ over periods which (mostly) do not exceed 2 days. Overall, the events observed in the Ardèche catchment are of moderate intensity - on average the maximum intensity of an event is $14.0 \mathrm{~mm} \mathrm{~h}^{-1}$ in the Ardèche as against $23.2 \mathrm{~mm} \mathrm{~h}^{-1}$ and $22.8 \mathrm{~mm} \mathrm{~h}^{-1}$ in the Beaume and Gardon catchments respectively.

\subsection{Spatial moments of catchment rainfall}

The spatial variability of these events is characterized by the statistical parameters $\delta_{1}$ and $\delta_{2}$ given in (Zoccatelli et al., 2011). These "spatial moments of catchment rainfall" provide a description of the interactions between spatial rainfall organization and basin morphology.

In order to meaningfully define $\delta_{1}$ and $\delta_{2}$, we introduce $\eta_{i}$ the flow distance from the catchment cell $i$ to the outlet. The flow distance average $\overline{\eta(P)}$ from the rainfall distribution to the outlet is defined as:

$\overline{\eta(P)}=\frac{1}{P} \sum_{i} p_{i} \cdot \eta_{i}$

where $p_{i}$ is the cumulative rainfall over the cell $i$ and $P$ the total cumulative rainfall over the catchment. Similarly the flow distance average $\overline{\eta(A)}$ from the catchment area distribution to the outlet is defined as follows:

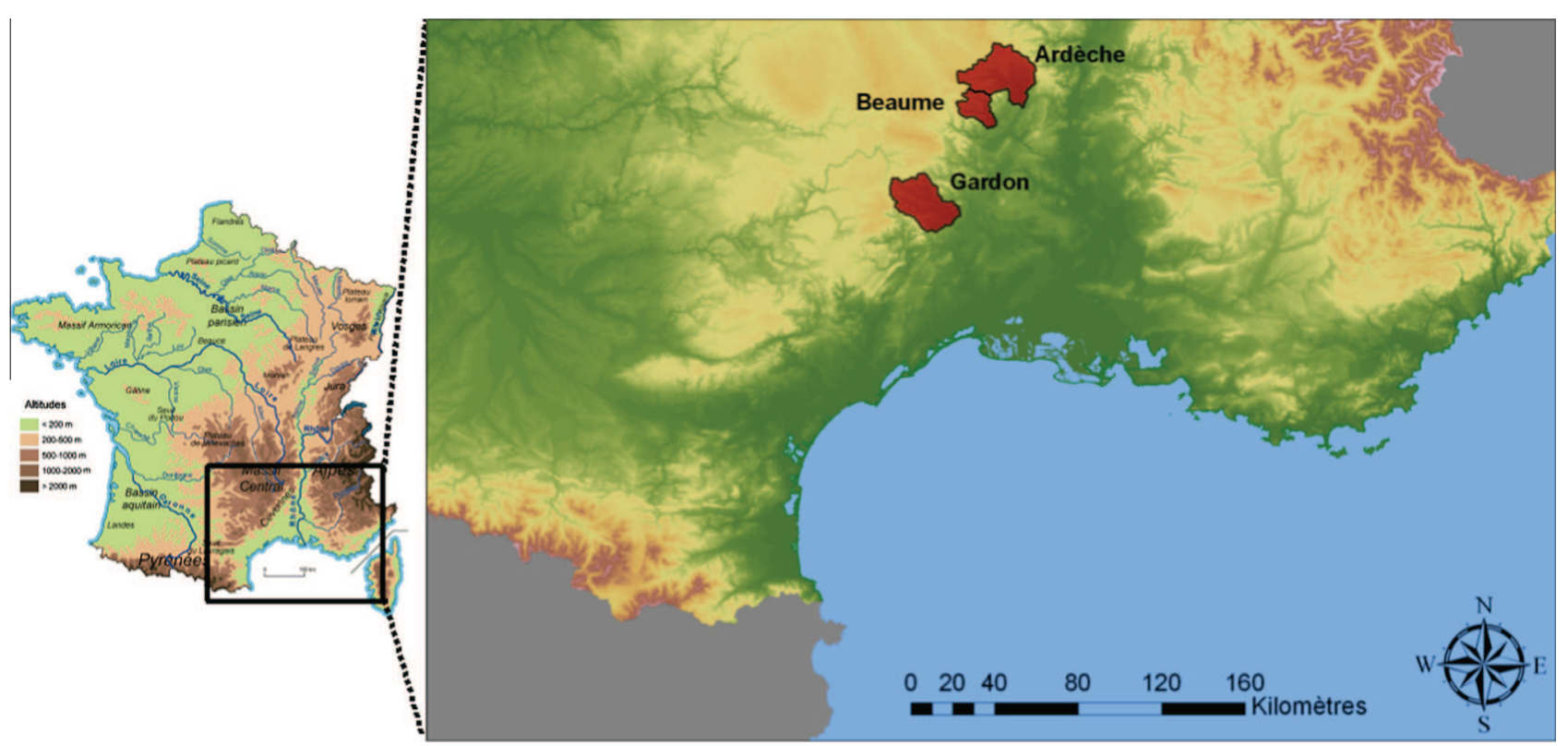

Fig. 2. Locations of the Ardèche, Beaume and Gardon catchments (red) in the Mediterranean area. (For interpretation of the references to color in this figure legend, the reader is referred to the web version of this article.) 
Table 2

Event characteristics and MARINE performances (bold) for the Beaume catchment.

\begin{tabular}{|c|c|c|c|c|c|c|c|c|}
\hline Date & Cumul (mm) & Time (h) & $I_{\max }^{\mathrm{a}}\left(\mathrm{mm} \mathrm{h}^{-1}\right)$ & $\delta_{1}{ }^{\mathrm{b}}$ & $\delta_{2}{ }^{\mathrm{b}}$ & $Q_{\max }\left(\mathrm{m}^{3} \mathrm{~s}^{-1}\right)$ & $\Theta_{i n i}{ }^{\mathrm{c}}(\%)$ & $\mathbf{N S}^{\mathrm{d}}$ \\
\hline $18 / 10 / 2006$ & 203 & 31 & 26.2 & 1.14 & 0.53 & 228 & 55 & 0.62 \\
\hline $16 / 11 / 2006$ & 128 & 38 & 17.4 & 1.01 & 0.73 & 238 & 57 & 0.56 \\
\hline $18 / 04 / 2008$ & 88 & 37 & 14.9 & 1.07 & 0.72 & 159 & 53 & 0.57 \\
\hline $20 / 10 / 2008$ & 198 & 26 & 23.3 & 0.88 & 0.8 & 284 & 55 & 0.88 \\
\hline $31 / 10 / 2008$ & 285 & 83.5 & 22.7 & 1.11 & 0.61 & 305 & 65 & 0.89 \\
\hline $05 / 05 / 2010$ & 56.5 & 7 & 20.9 & 0.97 & 0.8 & 153 & 54 & 0.55 \\
\hline $03 / 11 / 2011$ & 413 & 105 & 37 & 1.17 & 0.61 & 373 & 51 & 0.77 \\
\hline
\end{tabular}

a Maximal intensity.

b $\delta_{1}$ and $\delta_{2}$ correspond to the spatial parameters which characterize the rainfall (Zoccatelli et al., 2011).

c The initial water content of the soil corresponds to the outputs of the SIM model (Habets et al., 2008).

${ }^{d}$ NS = Nash-Sutcliffe coefficient.

Table 3

Event characteristics and MARINE performances (bold) for the Gardon catchment.

\begin{tabular}{|c|c|c|c|c|c|c|c|c|}
\hline Date & Cumul (mm) & Time (h) & $I_{\max }^{(a)}\left(\mathrm{mm} \mathrm{h}^{-1}\right)$ & $\delta_{1}^{(b)}$ & $\delta_{2}^{(b)}$ & $Q_{\max }\left(\mathrm{m}^{3} \mathrm{~s}^{-1}\right)$ & $\Theta_{i n i}^{(c)}(\%)$ & $\mathbf{N} \mathbf{S}^{(d)}$ \\
\hline 21/09/1994 & 243 & 46 & 34.8 & 1.04 & 0.81 & 774.7 & 49 & 0.77 \\
\hline 18/09/1995 & 144 & 25 & 20.8 & 1.06 & 0.66 & 945.8 & 57 & 0.06 \\
\hline $03 / 10 / 1995$ & 267 & 45 & 33.4 & 0.85 & 0.51 & 1607 & 57 & 0.59 \\
\hline 13/10/1995 & 173 & 32 & 22.7 & 0.85 & 0.57 & 1411.3 & 62 & 0.68 \\
\hline $10 / 11 / 1996$ & 216 & 57 & 14.3 & 1.03 & 0.69 & 692.5 & 56 & 0.68 \\
\hline $17 / 05 / 1999$ & 129 & 28 & 15.9 & 1.08 & 0.69 & 707 & 56 & -0.15 \\
\hline $28 / 09 / 2000$ & 198 & 29 & 22.6 & 1.03 & 0.77 & 1184 & 51 & 0.73 \\
\hline $22 / 10 / 2008$ & 108 & 28 & 18.6 & 0.61 & 0.51 & 1081 & 59 & 0.83 \\
\hline $31 / 10 / 2008$ & 191 & 41 & 21.1 & 1.14 & 0.39 & 1053 & 53 & 0.94 \\
\hline $10 / 11 / 2011$ & 245 & 39 & 13.9 & 1.04 & 0.72 & 1042 & 70 & 0.96 \\
\hline $14 / 03 / 2002$ & 65 & 11 & 36.2 & 1.0 & 0.55 & 666 & 57 & 0.35 \\
\hline $08 / 09 / 2002$ & 283 & 22 & 44.6 & 0.74 & 0.87 & 3630 & 49 & 0.84 \\
\hline $18 / 10 / 2006$ & 231 & 34 & 20.1 & 1.06 & 0.66 & 1480 & 56 & 0.85 \\
\hline
\end{tabular}

Table 4

Event characteristics and MARINE performances (bold) for the Ardèche catchment.

\begin{tabular}{|c|c|c|c|c|c|c|c|c|}
\hline Date & Cumul (mm) & Time $(\mathrm{h})$ & $I_{\max }^{(a)}\left(\mathrm{mm} \mathrm{h}^{-1}\right)$ & $\delta_{1}^{(b)}$ & $\delta_{2}^{(b)}$ & $Q_{\max }\left(\mathrm{m}^{3} \mathrm{~s}^{-1}\right)$ & $\Theta_{i n i}^{(c)}(\%)$ & $\mathbf{N S} \mathbf{S}^{(d)}$ \\
\hline $18 / 10 / 2006$ & 124 & 27 & 11.4 & 1.18 & 0.47 & 551 & 57 & 0.93 \\
\hline $16 / 11 / 2006$ & 157 & 28 & 15.7 & 0.99 & 0.78 & 710 & 58 & 0.89 \\
\hline $18 / 04 / 2008$ & 66 & 32 & 11.9 & 1.08 & 0.70 & 297 & 55 & 0.73 \\
\hline $20 / 10 / 2008$ & 182 & 23 & 16.2 & 0.94 & 0.73 & 970 & 56 & 0.92 \\
\hline $31 / 10 / 2008$ & 173 & 45 & 11.3 & 1.17 & 0.56 & 1010 & 65 & 0.86 \\
\hline $05 / 05 / 2010$ & 51 & 7.8 & 16.8 & 0.99 & 0.74 & 453 & 56 & 0.72 \\
\hline $03 / 10 / 2011$ & 351 & 102 & 21.4 & 1.12 & 0.66 & 893 & 47 & 0.91 \\
\hline
\end{tabular}

$\overline{\eta(A)}=\frac{1}{N} \sum_{i} \eta_{i}$

where $N$ is the number of catchment cells (cell areas are constant, equal to 1$)$.

According to Zoccatelli et al. (2011) definition, the first index $\delta_{1}$ is calculated as follows:

$\delta_{1}=\frac{\frac{1}{P} \sum_{i} p_{i} \cdot \eta_{i}}{\frac{1}{A} \sum_{i} \eta_{i}}=\frac{\overline{\eta(P)}}{\overline{\eta(A)}}$

Eq. (3) illustrates the physical meaning of the index $\delta_{1}$. It represents the ratio between the flow distance average from rainfall accumulation distribution to the outlet $\overline{\eta(P)}$ and the flow distance average from catchment area distribution to the outlet $\overline{\eta(A)}$. It quantifies the rainfall location towards the outlet of the catchment. $\delta_{1}<1$ indicates for example, that rainfall is generally located close to the outlet (see Fig. 3).

The second index $-\delta_{2}-$ corresponds to the ratio between the second central moment of the same series: the flow distance

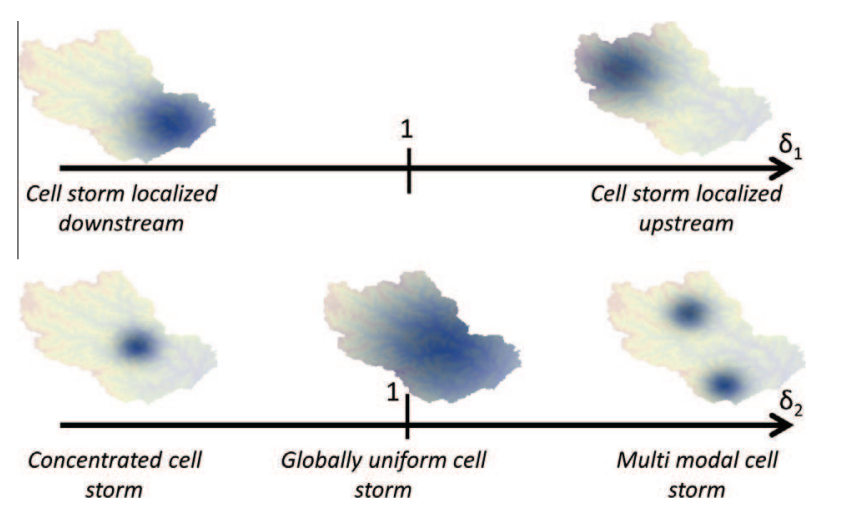

Fig. 3. Characterization of rainfall spatial variability using the $\delta_{1}$ (top) and $\delta_{2}$ (bottom) parameters.

distribution from rainfall accumulation to the outlet $\eta(P)$; and the flow distance distribution from catchment areas to the outlet $\eta(A)$. 
This second index quantifies the variability of the hydrological distances to the outlet weighted by the spatiotemporal organization of rainfall in comparison to the variability of those which are characteristic of the catchment. $\delta_{2}<1$ indicates that the rainfall center of mass is collected in a smaller region than the catchment surface area; the rainfall storm cell is spatially monomodal. On the contrary, $\delta_{2}>1$ indicates that the spatiotemporal distribution of rainfall is multimodal (see Fig. 3 ).

$$
\begin{aligned}
& \operatorname{var}\left(\eta^{a}\right)=\frac{1}{A} \sum_{i} \eta_{i}^{2}-\left(\frac{1}{A} \sum_{i} \eta_{i}\right)^{2} \\
& \operatorname{var}\left(\eta^{p}\right)=\frac{1}{P} \sum_{i} p_{i} \cdot \eta_{i}^{2}-\left(\frac{1}{P} \sum_{i} p_{i} \cdot \eta_{i}\right)^{2} \\
& \delta_{2}=\frac{\operatorname{var}\left(\eta^{p}\right)}{\operatorname{var}\left(\eta^{a}\right)}
\end{aligned}
$$

According to the index $\delta_{1}$, it can be observed that the events in the Gardon region tend to occur downstream of the catchment (Table 3), in contrast to the Beaume and Ardèche regions where forcing is more significant at the heads of the catchment areas (Tables 2 and 4). The parameter $\delta_{2}$, which characterizes the concentration of rainfall on the catchment, indicates a generally high concentration (mean $\delta_{2}$ value at 0.6 , i.e. less than 1 ).

\section{Assessment of the FFG method}

\subsection{The FFG method}

The FFG method consists of calculating, for a given forecasting period, the threshold rainfall $[L]$ (taken to be uniform in time and space) which gives rise to a hydrological response exceeding a threshold flow. In its operational mode, the FFG method takes the form of a diagram: the threshold rainfalls are given for different forecasting intervals as well as for different initial wetness conditions (see Fig. 4). The task of the forecaster is then to compare the weather forecasts with the threshold rainfall which corresponds to the given situation.

FFG methods need firstly threshold flows calculation before runoff calculations. Carpenter et al. (1999) enumerates two ways to estimate a catchment threshold flow; either using historical data and considering the 2 yr-return period or using the bankfull discharge as threshold flow. Reed et al. (2007) proposes a threshold frequency approach that relies on model-simulated return flows.

Similarly runoff calculation could derive from different procedures. The original one consists in computing surface runoff with the Sacramento Soil Moisture Accounting model (SAC-SMA; Anderson, 1973). Threshold rainfalls derive from model calculation with a uniform rainfall forcing over the accumulation period. Soil moisture state is taken into account through SAC-SMA model parameters. Schmidt et al. (2007) developed a gridded FFG (GFFG) method to calculate threshold rainfalls at finer and more relevant scale toward flash flood processing (basins of approximately

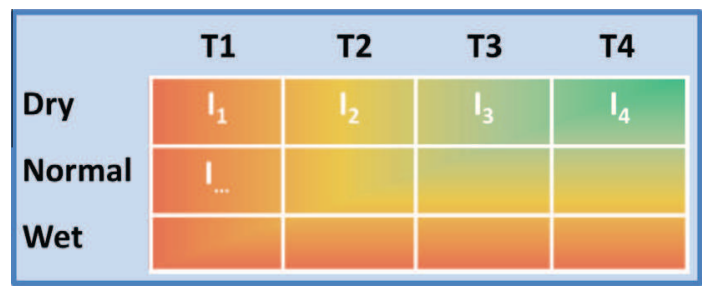

Fig. 4. A possible example of the flash flood forecasting diagram via the FFG method. The threshold intensity is given for various forecast lead times $\left(T_{1}, T_{2}, \ldots\right)$ and different initial wetness conditions (Dry, Normal, Wet).
$1000 \mathrm{~km}^{2}$ for SAC-SMA simulations). The Soil Conservation Service Curve Number (SCS CN, Mishra and Singh, 2003) model is adapted to calculate threshold rainfalls taking into account physical properties and soil moistures states at a $4 \mathrm{~km} \times 4 \mathrm{~km}$ gridded scale. Norbiato et al. (2008) use a semi-distributed conceptual model (Moore, 1985) to assess FFG method in basins in Northeastern Italy and central France.

In this study, a 2 yr-return period flow is considered as threshold flow as it corresponds to the first level alert from the flood warning center in France (SCHAPI). The model used to calculate threshold rainfalls is the physically-based distributed MARINE (Roux et al., 2011, see Section 2). The choice is motivated by the fact that this model is currently used within the French flood forecasting system. Moreover, MARINE model implements a wide range of physiographic data distributed over all (or part) of the country: topographical (BD TOPO ${ }^{\circledR}$ ), pedological (BDSol-LR, INRA Robbez-Masson et al., 2002) and geological data (BD MillionGéol, BRGM). Likewise, the Météo-France SIM model (Habets et al., 2008) provides the soil moisture in France at a resolution of $8 \times 8 \mathrm{~km}$ each day. Like within the GFFG method, the physically-based, distributed model MARINE (see Section 2) makes use of all this information, calculating a threshold rainfall which includes the physiographic characteristics of the catchments, spatially distributed.

Threshold rainfall was used to be calculated over accumulation periods of 1, 3 and $6 \mathrm{~h}$. However, those accumulation periods are not relevant compared to the observed rainfall accumulation of the flash flood events of this study (Tables 2-4). In the present paper, accumulation period of the observed storms are considered to calculate threshold rainfall. Considering observed rainfall accumulation periods within the threshold rainfall calculation offers the possibility to compare the threshold rainfall values with the observed rainfall accumulations. FFG method is not directly applied but assessed testing the threshold rainfall estimation. The performances of the method are then evaluated by comparing this estimation with the observed threshold rainfall.

Hereafter threshold intensity of rainfall $\left[L \cdot T^{-1}\right]$ are considered instead of threshold rainfall $[L]$, as it is supposed to be less dependent of the accumulation period or forecast lead time. The reference accumulation period (hereafter referred as $T_{O B S}$ ) is defined as the period between the onset of precipitation and the threshold flow being exceeded by the observed flow. Fig. 5a illustrates the definition of $T_{O B S}$. Values of threshold flows of each catchment are given in Table 1.

Assuming this reference interval $T_{O B S}$, the mean precipitation intensity observed during this period $\left(I_{O B S}\right)$ constitutes a reference threshold intensity for the forecast duration $T_{O B S}$. Finally, $T_{O B S}$ is calculated as follows:

$\forall t \in\left[t_{0} ; T_{O B S}\right] Q_{0}\left(t<T_{O B S}\right)<Q_{\text {threshold }}$ and $Q_{0}\left(t=T_{O B S}\right)=Q_{\text {threshold }}$

where $Q_{0}(t)$ is the observed flow $\left(\mathrm{m}^{3} \mathrm{~s}^{-1}\right)$ as a function of time $t$ $(s), Q_{\text {threshold }}$ is the threshold flow $\left(\mathrm{m}^{3} \mathrm{~s}^{-1}\right), t_{0}$ is the date of onset of precipitation event $(\mathrm{s})$. whence

$I_{O B S}=\frac{1}{T_{O B S}-t_{0}} \int_{t=t_{0}}^{t=T_{O B S}} \frac{1}{A} \iint_{A} r(x, y, t) d x d y d t$

where $r(x, y, t)$ is the observed rainfall intensity as a function of time and space $\left(\mathrm{m} \mathrm{s}^{-1}\right)$.

For each event the threshold intensity $\left(I_{F F G}\right)$ is calculated via the FFG method using a forcing function $r_{u n i}$ within the MARINE hydrological model which is uniform in time and space (see Fig. 5b), over the interval $T_{O B S}$.

$I_{\text {FFG }}=\frac{1}{T_{\text {OBS }}-t_{0}} \int_{t=t_{0}}^{t=T_{\text {OBS }}} r_{\text {uni }} d t$ 
(a) Determination of Tobs and lobs

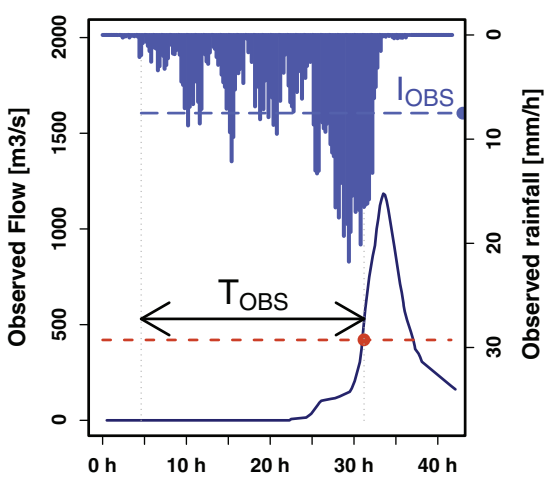

(b) FFG threshold computation

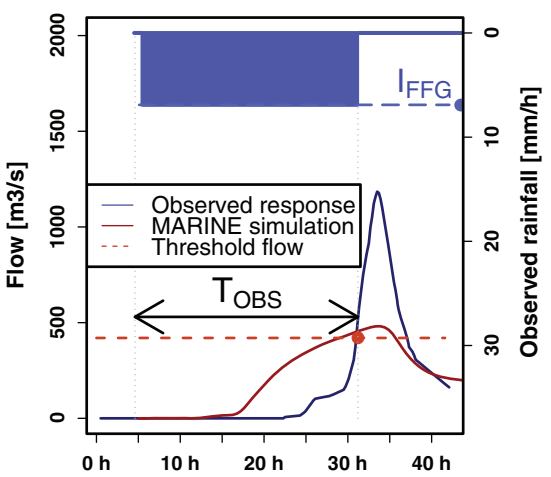

(c) MARINE threshold computation

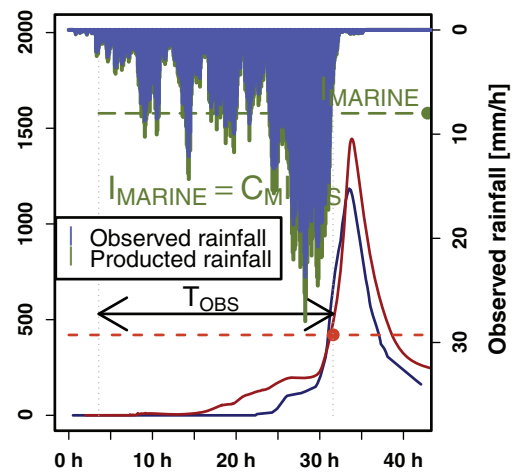

Fig. 5. Threshold intensities calculation. (a) Determination of the trigger interval $T_{O B S}$ from observations and calculation of trigger intensity $I_{O B S}$ ), i.e. the mean intensity observed over $T_{O B S}$. (b) Calculation of threshold intensity $\left(I_{F F G}\right)$ defined by the FFG method: uniform rainfall intensity exceeding the alert threshold during the trigger interval $T_{O B S}$. (c) Calculation of the threshold intensity $\left(I_{\text {MARINE }}\right)$; via hydrological simulation using the MARINE model; multiplication of the observed precipitation by a factor $C_{M}$ to obtain the exceedance of the alert threshold within a period $T_{O B S}$.

The forcing function $r_{u n i}\left(\mathrm{~m} \mathrm{~s}^{-1}\right)$ is calculated such as to obtain:

$\forall t \in\left[t_{0} ; T_{O B S}\right] Q_{S \text { uni }}\left(t<T_{O B S}\right)<Q_{\text {threshold }}$ and $Q_{s \text { uni }}\left(t=T_{O B S}\right)=Q_{\text {threshold }}$

where $Q_{s}$ uni $(t)$ is the flow $\left(\mathrm{m}^{3} \mathrm{~s}^{-1}\right)$ simulated by MARINE as a function of time using the forcing function $r_{\text {uni }}$. A comparison between $I_{F F G}$ and $I_{O B S}$ will enable the FFG method to be assessed.

On the other hand, in order to study the effect of the model choice on the results obtained, we calculate a third threshold:

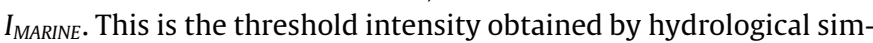
ulation of the product between observed rainfall and a coefficient $C_{M}$ such as to obtain a simulated flow which exceeds the threshold flow over the period $T_{O B S}$ (see Fig. 5c).

$I_{\text {MARINE }}=\frac{1}{T_{O B S}-t_{0}} \int_{t=t_{0}}^{t=T_{O B S}} \frac{1}{A} \iint_{A} C_{M} \times r(, x, y, t) d x d y d t$

The coefficient $C_{M}(-)$ is calculated such as to obtain:

$\forall t \in\left[t_{0} ; T_{O B S}\right] Q_{S}\left(t<T_{O B S}\right)<Q_{\text {threshold }}$ and $Q_{S}\left(t=T_{O B S}\right)=Q_{\text {threshold }}$.

where $Q_{s}(t)$ is the flow $\left(\mathrm{m}^{3} \mathrm{~s}^{-1}\right)$ simulated by MARINE as a function of time using the forcing function $C_{M} \times r(x, y, t)$. A comparison of $I_{\text {MARINE }}$ with $I_{O B S}$ will enable investigation regarding the influence of the model on the calculated threshold intensity to be examined.

\subsection{Results}

\subsubsection{Assessment of the MARINE model}

The objective is to assess the ability of the MARINE model to estimate a threshold intensity approaching that observed for the different events. Fig. 6 compares the observed threshold intensity $\left(I_{O B S}\right)$ with those obtained by hydrological simulation ( $I_{\text {MARINE }}$ ). Apart from one event in the Gardon (18/09/1995) the results for the Ardèche and Gardon catchments are homogeneous. Putting this event to one side, the relative difference between $I_{\text {MARINE }}$ and $I_{O B S}$ for the Gardon catchment is $16 \%$ on average. The relative difference is higher for the Ardèche (42\%). Overall, for these two catchments areas, the MARINE model provides satisfactory estimates of the threshold intensity with a mean of relative difference of $26 \%$ between $I_{O B S}$ and $I_{\text {MARINE }}$.

In the Beaume catchment area we note that there is a distinction between the events of high intensity and those of average intensity $(<5 \mathrm{~mm} / \mathrm{h})$. The MARINE model gives satisfactory results when the flood events being considered are sufficiently long $\left(T_{O B S}>2 t_{c}\right)$ when the intensity $I_{O B S}$ is moderate $\left(I_{O B S}<5 \mathrm{~mm} \mathrm{~h}^{-1}\right)$. By contrast, the sudden nature $\left(T_{O B S}<2 t_{c}\right)$ and/or the intense nature $\left(I_{\max }>25 \mathrm{~mm} \mathrm{~h}^{-1}\right)$ of events seems to degrade the accuracy of the results since the model then overestimates the trigger threshold intensity in the order of $100 \%$. The hydrographs (using the event of 03/11/2011 as an example in Fig. 7) show a delay in the simulation of the rising limb of the flood for the 3 events concerned (03/11/2011, 16/11/2006 and 18/10/2006), that might explain the overestimation of the trigger threshold intensity. Indeed, to ensure
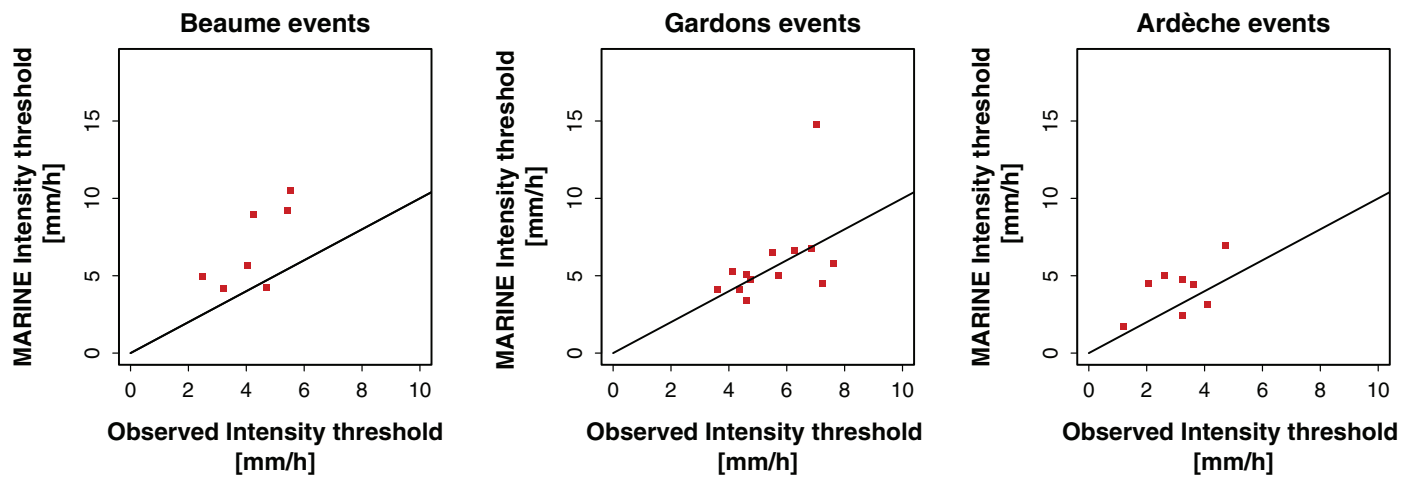

Fig. 6. Comparison between threshold intensities $I_{O B S}$ and $I_{\text {MARINE. }}$. 
03/11/2011 event on Beaume catchment

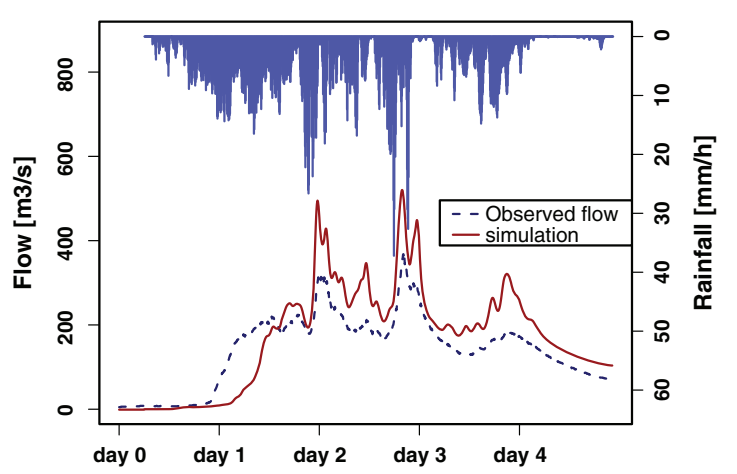

Fig. 7. Comparison between simulated and observed flows for the event of 03/11/ 2011 in the Beaume catchment.

that flow rate can reach $Q_{\text {threshold }}$ at $t=T_{O B S}$, the coefficient $C_{M}$ is forced to take large values, and consequently it makes $I_{\text {MARINE }}$ to overestimate $I_{O B S}$. Delays in rising limbs emphasize the uncertainty of the initial wetness condition that appears here to be critical for sudden and intense events.

\subsubsection{Assessment of the FFG method}

The comparison of the threshold intensities $I_{F F G}$ and $I_{O B S}$ (see Fig. 8) shows the similarities between the Gardon and Beaume catchments. We observe that the FFG method gives better results in these two catchments for events of lower magnitude intensity. This shows that the accuracy of rainfall intensity simulation is of lesser importance for these particular cases.

In contrast, we see a deviation from the FFG method when the events are particularly intense. The deterioration in the quality of the results with event magnitude is especially troublesome for the forecasting of flash floods. Focusing on the spatialisation of these events, we observe on Fig. 9(b) and (c) for the Gardon catchment a good correlation between the localized nature and the relative difference between $I_{O B S}$ and $I_{F F G}$ taken as a performance criterion of the FFG method (Coefficient of determination $R^{2}$ equal to 0.47 and 0.20 between $\delta_{1}$ index and the performance criterion and between $\delta_{2}$ index and the performance criterion, respectively). Threshold intensity calculated by the FFG method seems to be overestimated when the event combines a downstream location $\left(\delta_{1}<1\right)$ and a concentration on a low proportion of the catchment $\left(\delta_{2}<0.9\right)$. In the Beaume, however, no correlation is observed neither between $\delta_{1}$ index and the performance criterion $\left(R^{2}=0.01\right)$ nor between $\delta_{2}$ index and the performance criterion $\left(R^{2}=0.04\right)$. In this particular catchment, the deterioration in the results of the FFG method seems to be related to the limitations of the model that have already been mentioned in Section 4.2.1. Indeed the events for which the thresholds are overestimated on the Beaume catchment correspond to those showing a delay in the simulation of the rising limb.

The results are more homogeneous for the Ardèche catchment. However, the threshold intensity is overestimated. This result can be explained by an underestimate of the hydrological response by the forced distributed models with uniform rainfall (Arnaud et al., 1999; Tramblay et al., 2010): the spatial and/or temporal information for the precipitation is not negligible. The direct hydrological model $\left(I_{\text {MARINE }}\right)$ performs significantly better than the FFG method. The benefits of using a distributed model for a direct application of the FFG method with spatial uniform forcing seem therefore limited.

The construction of a new method for predicting flash floods was inspired by the results just highlighted. The meteorological events that give rise to flash floods are characterized by strongly localized rainfall events (Tables 2-4) which affect the hydrological response, and hence how it is modelled (Lobligeois, 2014). In calculating the threshold intensity, we propose to introduce information on the spatialisation of the forecast rainfall events. The objective is to reduce the amount by which the threshold intensity is overestimated while retaining the operational character of the FFG method.

\section{The spatialized FFG method (SFFG)}

\subsection{Description of the SFFG method}

The central idea of the SFFG method is to calculate threshold intensities that integrate rainfall spatial information. Contrary to within the FFG method and in order to be closer from the real processes, rainfall forcing is not assumed to be spatially uniform anymore. The SFFG method accounts for global spatial variability of forecasted storm through $\left(\delta_{1}, \delta_{2}\right)$ characterization. Indeed, rainfall spatial distribution with specific $\left(\delta_{1}, \delta_{2}\right)$ values are used to force the model and calculate threshold intensities. Focusing the study on the effect of spatial rainfall distribution, temporal dimension is ignored and only $\left(\delta_{1}, \delta_{2}\right)$ of the total cumulative storm are considered.

The characterization of spatial rainfall distribution by the $\left(\delta_{1}, \delta_{2}\right)$ pairs is motivated by the fact that it integrates relevant information regarding the impact on hydrological processes.
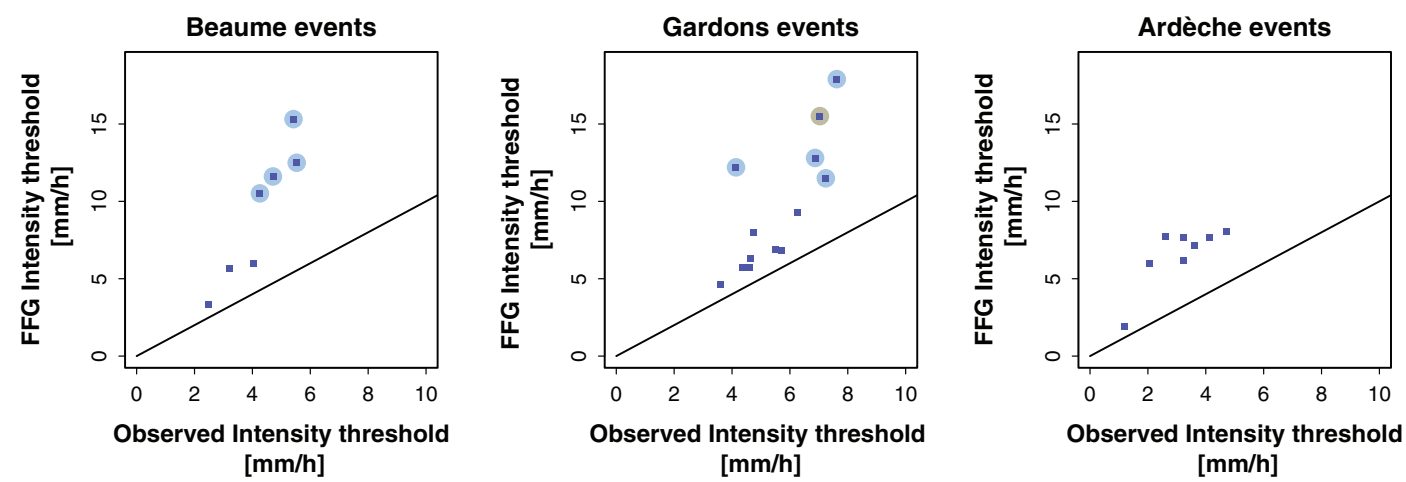

Fig. 8. Comparison between threshold intensities $I_{F F G}$ and $I_{O B S}$. The events for which the FFG method particularly overestimates the threshold intensity are highlighted by solid blue circles. In the Beaume catchment area, the threshold intensities of the events of 18/10/2006, 16/11/2006, 20/10/2008 and 03/11/2011 are overestimated by 126\%, $183 \%, 146 \%$ and $147 \%$ respectively. In the Gardon catchment area, the threshold intensities of the events of 03/10/1995, 13/10/1995, 14/03/2002 and 22/10/2008 are overestimated by $135 \%, 69 \%, 195 \%$ and $86 \%$ respectively. (For interpretation of the references to color in this figure legend, the reader is referred to the web version of this article.) 


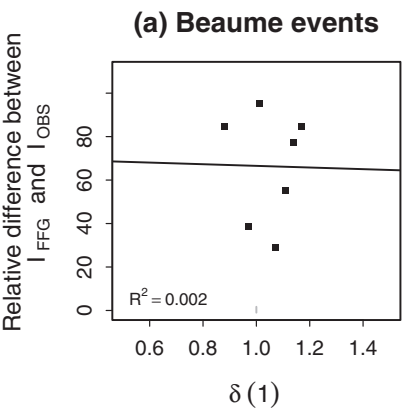

(d) Beaume events

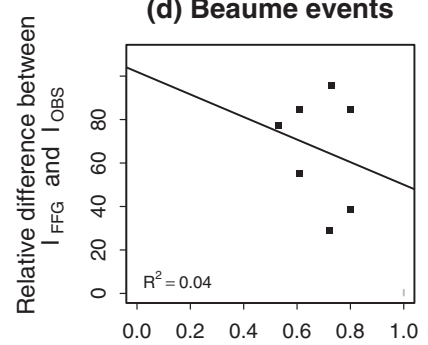

$\delta(2)$

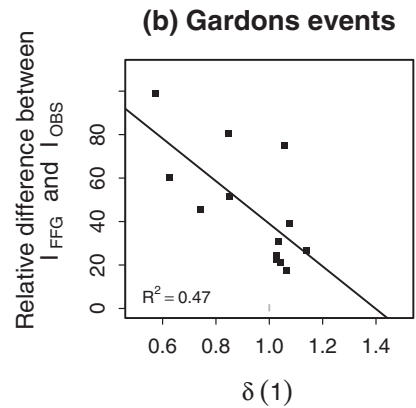

(e) Gardons events

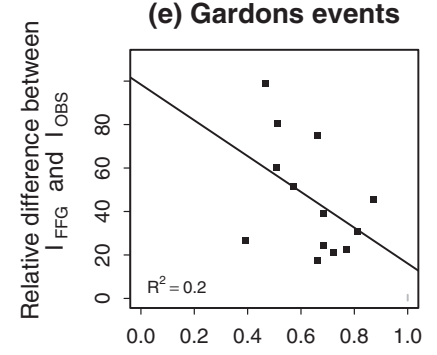

$\delta(2)$

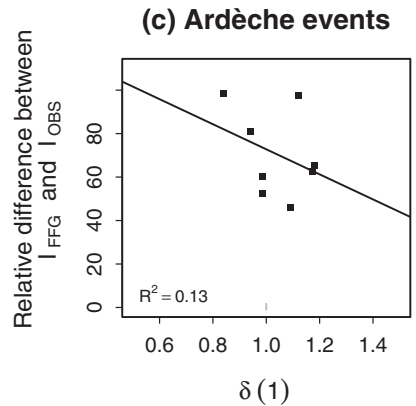

(f) Ardèche events

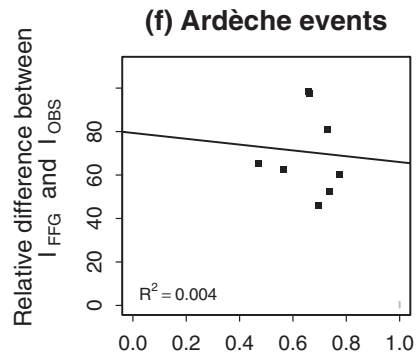

$\delta(2)$

Fig. 9. Relation between FFG method performances and $\left(\delta_{1}, \delta_{2}\right)$ rainfall spatial characteristics of events by catchment. Coefficient of determination $R^{2}$ is given for each catchment to assess correlation between FFG performances and $\left(\delta_{1}, \delta_{2}\right)$ variables.

Furthermore results on Section 4.2.2 show that $\left(\delta_{1}, \delta_{2}\right)$ characteristics of flash flood events could influence the performances of the FFG method.

The new threshold rainfall rate $I_{S F F G}\left(\delta_{1}, \delta_{2}\right)\left[\mathrm{L} \mathrm{T}^{-1}\right]$ represents the spatial averaged threshold rainfall rate required to cause threshold flow for a storm with the particular $\left(\delta_{1}, \delta_{2}\right)$ spatial characterization.

Rainfall spatial distributions with a wide range of spatial characterization is required in order to calculate threshold intensity $I_{S F F G}\left(\delta_{1}, \delta_{2}\right)$ for a wide range of $\left(\delta_{1}, \delta_{2}\right)$ pairs. Artificial storm cells with constrained spatial distribution are generated. Each distribution is defined as a sum of normal distributions where precipitation rates depend on the flow distance of the mesh $(x, y)$ as follows:

$$
\begin{aligned}
P(\eta(x, y))= & P_{M} \cdot \exp \left(-\frac{1}{2}\left(\frac{\eta(x, y)-\eta_{c}}{0.5 \sigma}\right)^{2}\right) \\
& +P_{m}\left[\exp \left(-\frac{1}{2}\left(\frac{\eta(x, y)-\overline{\eta(x, y)}}{\sigma}\right)^{2}\right)\right. \\
& \left.+\exp \left(-\frac{1}{2}\left(\frac{\eta(x, y)-\left(\eta_{\max }(x, y)-\eta_{c}\right)}{\sigma}\right)^{2}\right)\right]
\end{aligned}
$$

where $P(\eta(x, y))$ is the precipitation rate over the mesh $(x, y)$ located at a hydrological distance $\eta(x, y)$ from the outflow; $\eta_{c}$ is the hydrological distance at the outflow characteristic to the generated precipitation $\left(\eta_{c}\right.$ will vary from $0.5 \cdot \overline{\eta(x, y)}$ to $1.5 \cdot \overline{\eta(x, y)}$ to obtain a large value of upstream-downstream location); $\sigma$ is a convenient spreading of normal distributions fixed to $\eta_{\max }(x, y) / 4$; and $P_{M}$ and $P_{m}$ are parameters that are chosen in order to follow the condition:

$\frac{1}{A} \iint_{A} P(\eta(x, y)) d x d y=I_{S F F G}\left(\delta_{1}, \delta_{2}\right)$

This threshold rainfall rate $I_{S F F G}\left(\delta_{1}, \delta_{2}\right)$ is calculated for a specific spatial characterization $\left(\delta_{1}, \delta_{2}\right)$ following the expression:

$$
I_{S F F G}\left(\delta_{1}, \delta_{2}\right)=\frac{1}{T_{O B S}-t_{0}} \int_{t=t_{0}}^{t=T_{O B S}} \frac{1}{A} \iint_{A} P_{\delta_{1} \delta_{2}}(\eta(x, y)) d x d y d t
$$

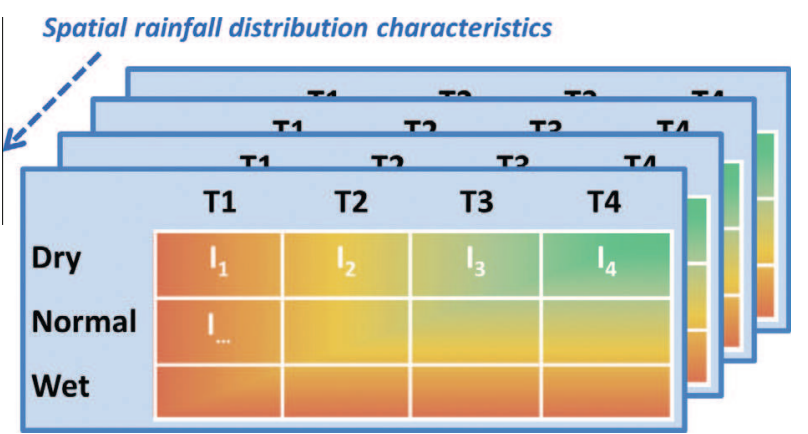

Fig. 10. Example of a series of flash flood forecasting diagrams using the SFFG method. Each diagram corresponds to rainfall spatialisation defined by the $\left(\delta_{1}, \delta_{2}\right)$ pair.

where $P_{\delta_{1} \delta_{2}}$ is an artificial rainfall distribution as described above with $\left(\delta_{1}, \delta_{2}\right)$ spatial characterization. The choice of $\eta_{c}$ will control the rainfall center of mass and therefore $\delta_{1}$ whereas $P_{M}$ and $p_{m}$ will control the spatial spread of the rainfall distribution, defined by $\delta_{2}$.

Forcing MARINE model with these artificial storm cells, a panel of $I_{S F F G}\left(\delta_{1}, \delta_{2}\right)$ is calculated and allows to build several flash flood forecasting diagrams (see Fig. 10), each being specific to a spatial characterization $\left(\delta_{1}, \delta_{2}\right)$.

\section{Application of the SFFG method}

Fig. 11 shows the spatial characteristics $\left(\delta_{1}, \delta_{2}\right)$ of the precipitation that have been generated for this study in each of the catchment areas. For each one, a set of 360 rainfall patterns has been used to force MARINE and calculate the associated 360 threshold rainfalls $I_{S F F G}\left(\delta_{1}, \delta_{2}\right)$. Moreover $I_{S F F G}\left(\delta_{1}, \delta_{2}\right)$ values have been linearly interpolated to derive $I_{S F F G}\left(\delta_{1}, \delta_{2}\right)$ for any $\left(\delta_{1}, \delta_{2}\right)$ pairs.

In the first step, the threshold intensities $I_{S F F G}\left(\delta_{1}, \delta_{2}\right)$ are calculated for a fixed initial wetness and forecast lead time. The variation of $I_{\text {SFFG }}$ as a function of $\left(\delta_{1}, \delta_{2}\right)$ will allow evaluating the effect of the spatialisation and the pertinence of including these 

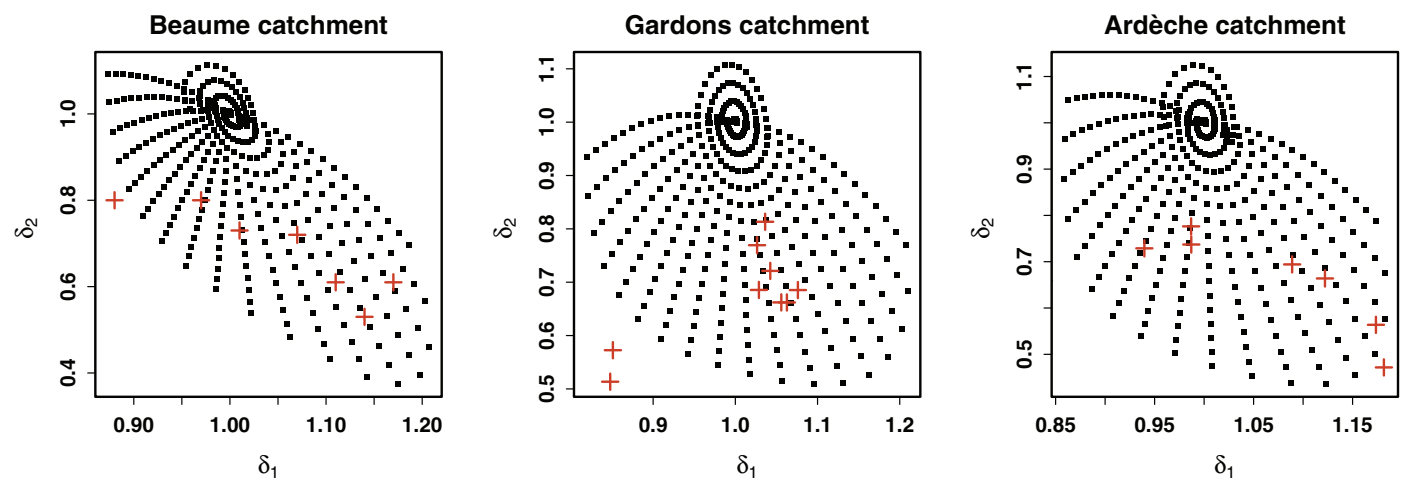

Fig. 11. $\left(\delta_{1}, \delta_{2}\right)$ pair of the synthetic events that have been processed on the Gardon, Ardèche and Beaume catchments (black); $\left(\delta_{1}, \delta_{2}\right)$ pair of studied observed events (orange). (For interpretation of the references to color in this figure legend, the reader is referred to the web version of this article.)

spatialisation characteristics. Second, the SFFG method is applied to the observed flash flood events.

\subsection{Variation of the threshold intensity with the spatialisation of rainfall events}

The threshold intensity $I_{S F F G}\left(\delta_{1}, \delta_{2}\right)$ is calculated for all the artificial precipitations shown in Fig. 11. The initial wetness conditions are set at $50 \%$. The threshold intensities $I_{S F F G}\left(\delta_{1}, \delta_{2}\right)$ are calculated for three forecast lead time of $t_{c} / 2, t_{c}$ and $3 t_{c}$ respectively, where $t_{c}$ is the concentration time of the catchment, as calculated by Bransby's formula (Pilgrim and Cordery, 1992): $t_{c}=\frac{21.3 L}{A^{0.1} 0^{0.2}}, L$ is the channel length (m), $A$ is the catchment area $\left(\mathrm{m}^{2}\right)$ and $S$ is the linear profile slope $(\mathrm{m} / \mathrm{m})$. Figs. $12-14$ show the results. The choice of $t_{c}$ is motivated in that it is representative of the lag time of the catchment. Referring to the first part of the study, the forecast lead time $t_{c}$ has the same function as $T_{o b s}$; they both represent the rainfall accumulation period.

With regard to the different threshold intensity surfaces $I_{S F F G}\left(\delta_{1}, \delta_{2}\right)$ obtained according to the catchment being studied and/or the forecast lead time, we observe a general variation in the threshold intensity with the spatial forcing characteristics. The downstream location as well as the concentrated nature of the rainfall events lead to a reduction in the threshold intensity. The upstream-downstream location $\left(\delta_{1}\right)$ appears to be the predominant information in calculating the threshold intensity, since the $I_{S F F G}\left(\delta_{1}, \delta_{2}\right)$ graphs show globally vertical isolines. The shorter the forecast lead time, the more sensitive is the threshold rainfall rate to the upstream-downstream location. Indeed, if the rainfall is mostly located downstream, the flow will arrive quickly at the outlet of the catchment and the threshold rainfall rate causing

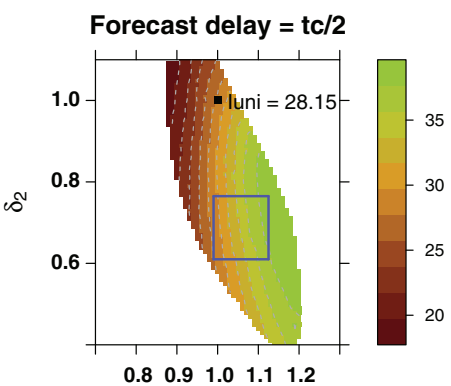

$\delta_{1}$

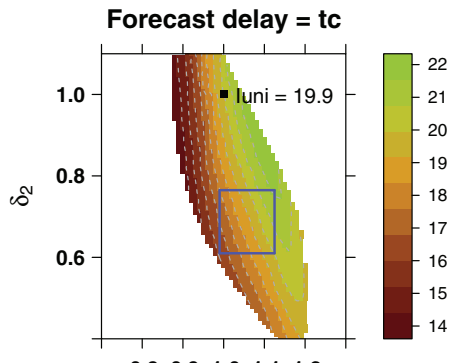

$\begin{array}{llllll}0.8 & 0.9 & 1.0 & 1.1 & 1.2\end{array}$

$\delta_{1}$

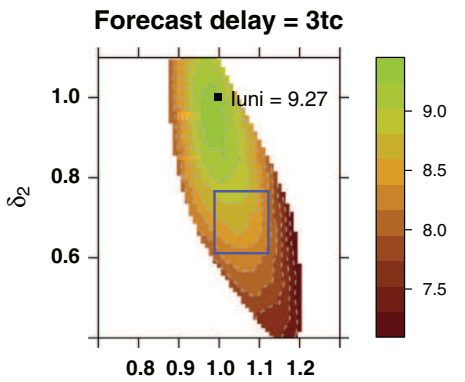

$\delta_{1}$

Fig. 12. $I_{\text {threshold }}$ on the Beaume catchment. The $I_{\text {threshold }}$ surface is calculated from a set of $360 I_{\text {threshold }}$ values that have been linearly interpolated. The blue rectangle delineates the zone characteristic of the spatial variability of the flash flood events studied. This zone is determined by the quartiles of the distributions of the $\left(\delta_{1}, \delta_{2}\right)$ pairs for these events (see Tables 2-4). (For interpretation of the references to color in this figure legend, the reader is referred to the web version of this article.)

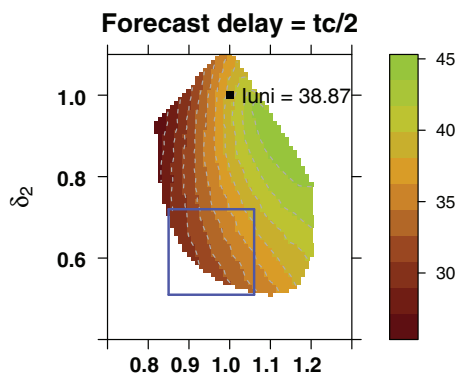

$\delta_{1}$

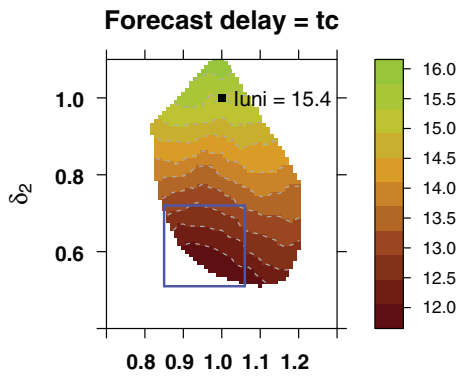

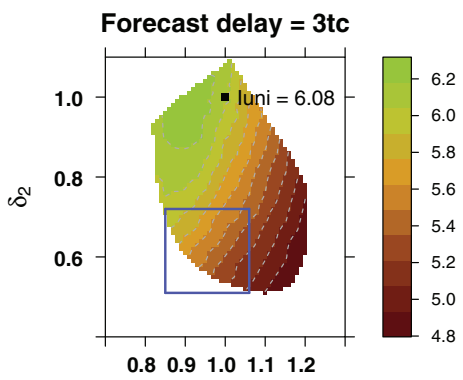

$\delta_{1}$

Fig. 13. $I_{\text {threshold }}$ on the Gardon catchment. 


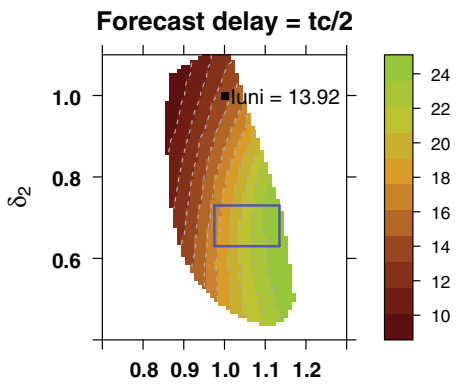

$\delta_{1}$

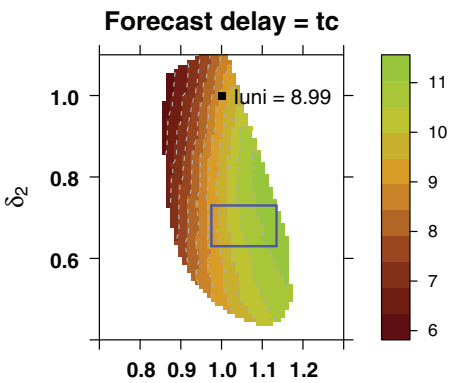

$\delta_{1}$

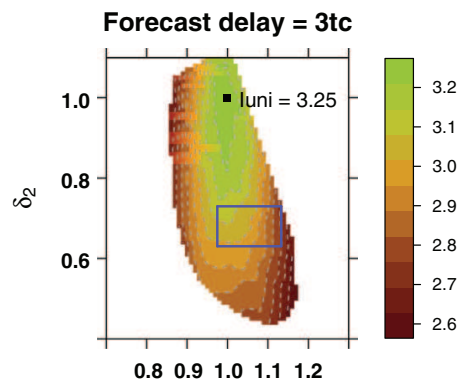

$\delta_{1}$

Fig. 14. $I_{\text {threshold }}$ on the Ardèche catchment.

threshold flow will therefore be lower. On the contrary, if the rainfall is mostly located upstream, the lag time for the flow to arrive at the outlet will be greater. In that case, the threshold rainfall rate causing threshold flow will be higher.

From a quantitative point of view, the variations in threshold intensity observed over the $I_{S F F G}\left(\delta_{1}, \delta_{2}\right)$ surfaces are significant regardless of the catchment area and forecast lead time. The threshold intensity scales vary from single to double. Focusing in particular on the spatial variabilities commonly encountered (inter-quartile zone represented by the blue rectangle in Figs. 12$14)$, the threshold intensity $I_{\text {SFFG }}\left(\delta_{1}, \delta_{2}\right)$ varies from $35.2 \%, 19.3 \%$ and $15.2 \%$ for forecast lead times of $t_{c} / 2, t_{c}$ and $3 t_{c}$ respectively. The shorter the forecast lead time, the more the inclusion of spatial variability affects the value of the threshold intensity. This fits in with the analysis of the results when the FFG method is applied to the three catchment areas (see Section 4.2.2). Indeed, it has been mentioned that the results of the original FFG method were worse for the events particularly intense and with short accumulation period; that is to say when the considered forecast lead times were small.

For the Gardon catchment area, we note a particular behavior of the threshold intensity $I_{S F F G}\left(\delta_{1}, \delta_{2}\right)$. Indeed, the observed variations differ from one forecast lead time to another. Under short lead time scenario (forecast lead time $=t_{c} / 2$ ), we find the general behavior described above with a threshold intensity decreasing with downstream location and rainfall concentration. The runoff response is mainly controlled by the downstream generated runoff since the travel time of runoff generated by the downstream catchment is close to the forecast lead time $t_{c} / 2$. On the other hand, for longer periods (forecast lead time $=3 t_{c}$ ) we observe smaller threshold intensities when precipitation is localized upstream. This unusual feature is explained by the particular spatial distribution of soil depths for this catchment. The upstream-generated runoff plays here a more significant role in influencing the runoff response at the outlet due to the similarity in magnitude of the travel time to the long forecast lead time. Moreover as the storage capacity of the ground upstream is minimal for this catchment (soil depth $\simeq 0.2 \mathrm{~m}$, see Fig. 15), it results in rapid runoff after saturation. Thus, this rapid runoff after saturation because of the minimal upstream soil storage capacity makes threshold intensities to be decreasing with the upstream storm localization. The importance of the interaction between the spatial variability of the rainfall events and that of the characteristics of the catchment is thus highlighted.

Hence the first conclusion we can draw is that the spatial distribution of rainfall events has a significant effect on the calculation of threshold intensities. Flash flood forecasting is sensitive to upstream-downstream location and the travel time of water. Those results are in accordance with Zoccatelli et al. (2011) and Mei et al. (2014) studies that show the significant influence of $\delta_{1}$ rainfall distribution information on flash and moderate flood response timing respectively. The amount by which precipitation is spread over an area alters the hydrological response, though this response information is of second order in detecting a flood exceeding some alert threshold flow. This spreading ( $\delta_{2}$ index) will have a major effect on the amplitude of the flood, but will be almost negligible in terms of the timing of the hydrological
Soil depth $[\mathrm{m}]$

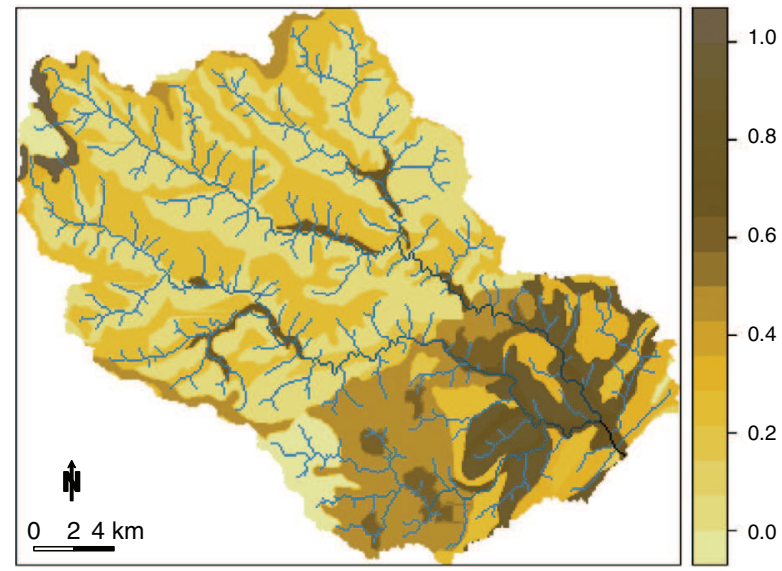

Soil condutivities $[\mathrm{mm} / \mathrm{h}]$

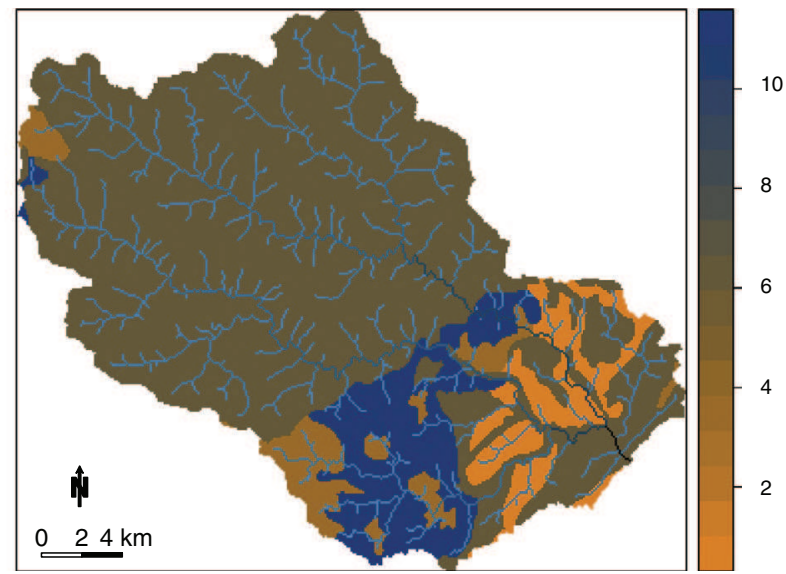

Fig. 15. Soil depths (left) and saturated hydraulic conductivities (right) distributions of the Gardon catchment. Soil properties are provided by the BD-sols Ardèche database (Robbez-Masson et al., 2002). They were established on the basis of soils surveys performed since 1990s for agronomic purposes. Soil depth and conductivities spatial representations show both contrasted properties along the upstream-downstream axis. 

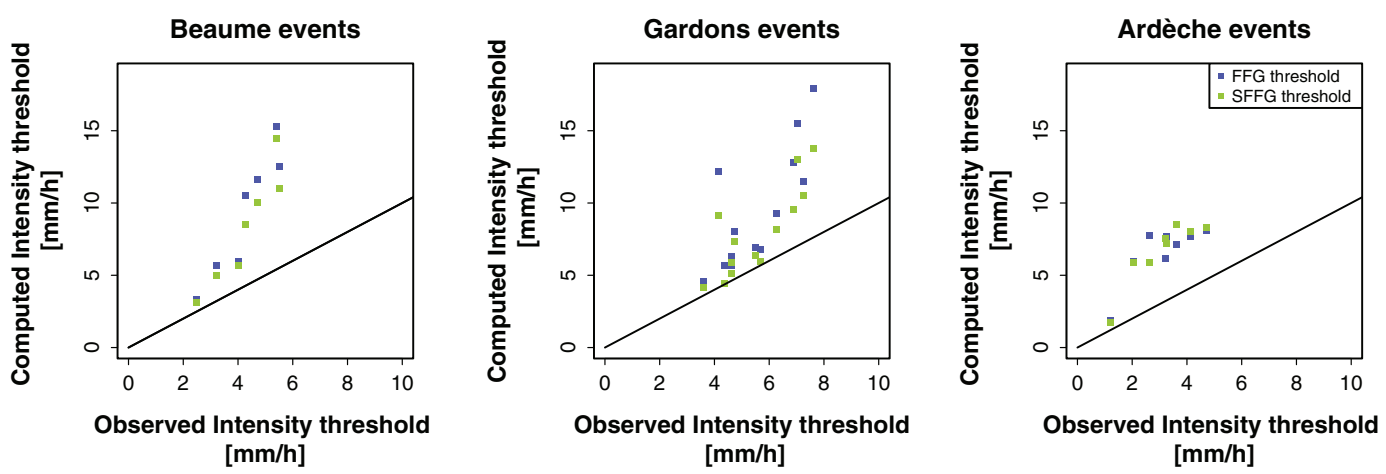

Fig. 16. Assessment of the SFFG method by comparing $I_{F F G}, I_{S F F G}, I_{O B S}$.

response, therefore it does not significantly impact flood rising alert.

There is of course an interaction between the spatial distribution of rainfall events and the spatial distribution of the storage capacity of the soil in the catchment area. The interaction between these two distributions can lead to either an attenuation or amplification of the hydrological response. A particular soil water storage configuration, as in the Gardon catchment (Fig. 15), may lead to real contrasts between the hydrological responses of two rainfall forcing with identical average intensity, but differing by their spatial distribution. Indeed, on the Gardon catchment, the soil depths and saturated hydraulic conductivities are much higher on the downstream part of the catchment than on the upstream part (Fig. 15). Therefore, different spatial rainfall organization interacting with this heterogeneous soil distribution will result in very different threshold rainfall patterns: travel time of water usually controlled by the flow distance is here shortened on upstream catchment by rapid runoff generation processes after saturation. In this case, it results in an inhibition of the effects of the upstream-downstream rainfall center of mass localization $\left(\delta_{1}\right)$. It might be clearly observed on the example of the forecast lead time tc, where almost horizontal isopleths are drawn on the $I_{S F F G}\left(\delta_{1}, \delta_{2}\right)$ surface (center panel on Fig. 13).

\subsubsection{Assessment of FFG and SFFG methods for the 27 events}

The SFFG method is now applied to the 27 events considered in the study. A threshold intensity is determined using the diagrams shown in Figs. 12-14. Just as in the assessment of the FFG method, the threshold intensity is calculated for the observed trigger period. On the basis of each diagram constructed for a forecast lead time $T_{O B S}$, the threshold intensity corresponding to the spatial characteristics $\left(\delta_{1}, \delta_{2}\right)$ of the observed precipitation events is extracted to form the threshold intensity $I_{S F F G}$. Fig. 16 compares the threshold intensities obtained with the FFG and SFFG methods respectively.

In the Beaume and Gardon catchments we observe a consistent reduction in the model threshold intensity when calculated by the new method. The reduction in the Gardon threshold intensity is all the more significant when the events are localized overall downstream of the catchment. Between the FFG and SFFG methods, the relative difference between the observed and calculated threshold intensities falls by $20 \%$ on average for these two catchments. However, it is observed that the threshold intensity is still overestimated for events of high intensity. For the Beaume, this can be explained in part by a poor soil wetness initialisation (see Section 4.2.1).

On the other hand, for the Ardèche catchment no improvement in the forecasting between the two methods is observed. The model threshold intensity attributed to a uniform rainfall event is smaller than that in the inter-quartile zone (see Fig. 14). In fact, the FFG method gives already generally good results on this catch- ment. Note that the Ardèche catchment is characterized by maximum intensity events which are smaller than those studied in the other catchments. It seems that rainfall spatial distribution information is more significant for flood events of strong intensity which explains the lack of improvement of the FFG method for flood events with smaller rainfall intensities.

We therefore observe a variable improvement in calculating threshold intensities using the SFFG method. Indeed, the effects due to the spatial distribution of rainfall differ from one catchment to another. That depends not only on the intensity of the event but also on the spatial heterogeneity of the physiographic characteristics of the catchment being studied.

\section{Conclusions}

Three catchment areas were investigated as a test case for the application of a new methodology in forecasting flash floods. Based on events observed over two decades, two operational forecasting methods, differentiated by the inclusion of spatial information for rainfall events, were applied.

The FFG method assessment to three catchment areas demonstrates the limitations of the method in that it significantly overestimates the threshold intensities leading to alerts being triggered. The forecasting results using this method are not uniform. For flash flood events associated with relatively low intensities, the use of the FFG method to predict whether the alert threshold flow will be exceeded is well established overall. On the other hand, for events of high intensity the FFG method significantly overestimates the intensity necessary to exceed the threshold flow. A new method for predicting flash floods incorporating information relating to the spatialisation of rainfall events has been proposed. The MARINE distributed model is used to obtain threshold intensity diagrams as a function of the forecast lead time and initial wetness conditions, but also the extent to which rainfall events are spread out and located upstream or downstream in the catchment.

The proposed SFFG method provides encouraging improvements as compared with the FFG method. In addition, it offers the potential to analyze the sensitivity of the hydrological response to the spatial characteristics of the precipitation events as a function of the forecast lead time. The prediction of flash flooding is sensitive to upstream/downstream location, in particular when the forecast lead times are short. The extent to which rainfall events are spread out over the catchment appears in the study as secondary information in calculating a warning threshold intensity.

However, any improvement in calculating the threshold intensity using the SFFG method should not be taken for granted. The effect of the spatial variability of rainfall events is significant for events of large amplitude. We may also note the differences in improvement among catchments when using the SFFG method. 
Factors other than the spatial distribution of rainfall probably influence the results. The effect of the spatial variability of precipitation events is inherent in its interaction with other spatial distributions such as those of soil properties. The inclusion of factors characteristic of this interaction would seem to be appropriate in making a better assessment of the amplification or attenuation of the hydrological response.

\section{References}

Anderson, E.A., 1973. National Weather Service River Forecast System: Snow Accumulation and Ablation Model. U.S. Dept. of Commerce, National Oceanic and Atmospheric Administration, National Weather Service, Washington, D.C. <http://www.lib.noaa.gov/uhtbin/cgisirsi/?ps=wAadjmPBbM/SILVERSPRG/564 10010/9>

Anquetin, S., Braud, I., Vannier, O., Viallet, P., Boudevillain, B., Creutin, J.D., Manus, C., 2010. Sensitivity of the hydrological response to the variability of rainfall fields and soils for the Gard 2002 flash-flood event. J. Hydrol. 394, 134-147. http://dx. doi.org/10.1016/j.jhydrol.2010.07.002, Flash Floods: Observations and Analysis of Hydrometeorological Controls. <http://www.sciencedirect.com/science/ article/pii/S0022169410004154>.

Arnaud, P., Lavabre, J., Masson, J., 1999. Amélioration des performances d'un modèle stochastique de génération de hyétogrammes horaires: application au pourtour méditerranéen français. Rev. sci. de l'eau/J. Water Sci. 12, 251-271. http://dx doi.org/10.7202/705351ar, <http://id.erudit.org/iderudit/705351ar>.

Ayral, P.A. Sauvagnargues-Lesage, S. Bressand, F, 2005. Contribution à la spatialisation du modèle opérationnel de prévision des crues éclair althaïr. Etud. géogr. physiqueéogr. phys. 32, 75-97.

Beven, K.J., Kirkby, M.J., 1979. A physically based, variable contributing area mode of basin hydrology/un modèle à base physique de zone d'appel variable de l'hydrologie du bassin versant. Hydrol. Sci. Bull. 24, 43-69. http://dx.doi.org/ $10.1080 / 02626667909491834$

Bressand, F., 2002. Le projet altha du service d'annonce des crues du Gard. La houille Blanche 2, 64-68. http://dx.doi.org/10.1051/lhb/2002024.

Carpenter, T., Sperfslage, J., Georgakakos, K., Sweeney, T., Fread, D., 1999. Nationa threshold runoff estimation utilizing $\{$ GIS $\}$ in support of operational flash flood warning systems. J. Hydrol. 224, 21-44. http://dx.doi.org/10.1016/S0022-1694 (99)00115-8, <http://www.sciencedirect.com/science/article/pii/ S0022169499001158>

CKAN, 2013. Emdat - The International Emergency Disasters Database.

Delrieu, G., Nicol, J., Yates, E., Kirstetter, P.E., Creutin, J.D., Anquetin, S., Obled, C. Saulnier, G.M., Ducrocq, V., Gaume, E., Payrastre, O., Andrieu, H., Ayral, P.A. Bouvier, C., Neppel, L., Livet, M., Lang, M., du Châtelet, J.P., Walpersdorf, A. Wobrock, W., 2005. The catastrophic flash-flood event of 8-9 September 2002 in the Gard region, France: a first case study for the Cévennes-Vivarais mediterranean hydrometeorological observatory. J. Hydrometeorol. 6, 34-52. http://dx.doi.org/10.1175/JHM-400.1.

Garambois, P.A., Roux, H., Larnier, K., Castaings, W., Dartus, D., 2013. Characterization of process-oriented hydrologic model behavior with temporal sensitivity analysis for flash floods in mediterranean catchments. Hydrol. Earth Syst. Sci. 17, 2305-2322. http://dx.doi.org/10.5194/hess-17. 2305-2013, <http://www.hydrol-earth-syst-sci.net/17/2305/2013/>.

Garambois, P.A., Roux, H., Larnier, K., Labat, D., Dartus, D., 2015a. Characterization of catchment behaviour and rainfall selection for flash flood hydrological mode calibration: catchments of the eastern pyrenees. Hydrol. Sci. J. 60, 424-447. http://dx.doi.org/10.1080/02626667.2014.909596.

Garambois, P.A., Roux, H., Larnier, K., Labat, D., Dartus, D., 2015b. Parameter regionalization for a process-oriented distributed model dedicated to flash floods. J. Hydrol. 525, 383-399. http://dx.doi.org/10.1016/j.jhydrol.2015.03.052.

Gaume, E., Bain, V., Bernardara, P., Newinger, O., Barbuc, M., Bateman, A., Blaskovicova, L., Blschl, G., Borga, M., Dumitrescu, A., Daliakopoulos, I., Garcia, J., Irimescu, A., Kohnova, S., Koutroulis, A., Marchi, L., Matreata, S., Medina, V., Preciso, E., Sempere-Torres, D., Stancalie, G., Szolgay, J., Tsanis, I., Velasco, D., Viglione, A., 2009. A compilation of data on european flash floods. J. Hydrol. 367, 70-78. http://dx.doi.org/10.1016/j.jhydrol.2008.12.028, <http:// www.sciencedirect.com/science/article/pii/S0022169409000079>.

Georgakakos, K.P., 1986. A generalized stochastic hydrometeorological model for flood and flash-flood forecasting: 1. Formulation. Water Resour. Res. 22, 20832095. http://dx.doi.org/10.1029/WR022i013p02083.

Habets, F., Boone, A., Champeaux, J.L., Etchevers, P., Franchisteguy, L., Leblois, E., Ledoux, E., Le Moigne, P., Martin, E., Morel, S., 2008. The Safran-Isba-Modcou hydrometeorological model applied over France. J. Geophys. Res.: Atmos. (1984-2012) 113. http://dx.doi.org/10.1029/2007JD008548, <http:// onlinelibrary.wiley.com/doi/10.1029/2007JD008548/abstract>.
Le Lay, M. Saulnier, G.M., 2007. Exploring the signature of climate and landscape spatial variabilities in flash flood events: case of the 8-9 September 2002 Cévennes-Vivarais catastrophic event. Geophys. Res. Lett. 34. http://dx.doi.org/ 10.1029/2007GL029746.

Lobligeois, F. 2014. Mieux connaitre la distribution spatiale des pluies améliore-t-il la modélisation des crues? Ph.D. thesis. AgroParisTech, Paris. <http://webgr. irstea.fr/wp-content/uploads/2014/09/2014_lobligeois_these.pdf >.

Marchi, L., Borga, M., Preciso, E., Gaume, E., 2010. Characterisation of selected extreme flash floods in Europe and implications for flood risk management. J. Hydrol. 394, 118-133, http://dx.doi.org/10.1016/j.jhydrol.2010.07.017, Flash Floods: Observations and Analysis of Hydrometeorological Controls. <http:// www.sciencedirect.com/science/article/pii/S0022169410004427>

Mei, Y., Anagnostou, E.N., Stampoulis, D., Nikolopoulos, E.I., Borga, M., Vegara, H.J., 2014. Rainfall organization control on the flood response of mild-slope basins. J. Hydrol. 510, 565-577. http://dx.doi.org/10.1016/j.jhydrol.2013.12.013, <http:// www.sciencedirect.com/science/article/pii/S0022169413009104>

Michaud, J., Sorooshian, S., 1994. Comparison of simple versus complex distributed runoff models on a midsized semiarid watershed. Water Resour. Res. 30, 593 605. http://dx.doi.org/10.1029/93WR03218.

Mishra, S.K., Singh, V.P., 2003. Soil Conservation Service Curve Number (SCS-CN) Methodology, vol. 42. Springer Science \& Business Media. http://dx.doi.org/ 10.1007/978-94-017-0147-1.

Mogil, H.M., Monro, J.C., Groper, H.S., 1978. NWS's flash flood warning and disaster preparedness programs. Bull. Am. Meteorol. Soc. 59, 690-699. http://dx.doi.org/ 10.1175/1520-0477(1978)059<0690:NFFWAD>2.0.CO;2.

Moore, R.J., 1985. The probability-distributed principle and runoff production at point and basin scales. Hydrol. Sci. J. 30, 273-297. http://dx.doi.org/10.1080/ 02626668509490989.

Morin, E., Yakir, H., 2014. Hydrological impact and potential flooding of convective rain cells in a semi-arid environment. Hydrol. Sci. J. 59, 1353-1362. http://dx. doi.org/10.1080/02626667.2013.841315.

Norbiato, D., Borga, M., Esposti, S.D., Gaume, E., Anquetin, S., 2008. Flash flood warning based on rainfall thresholds and soil moisture conditions: an assessment for gauged and ungauged basins. J. Hydrol. 362, 274-290. http:/ dx.doi.org/10.1016/j.jhydrol.2008.08.023, www.sciencedirect.com/science/article/pii/S0022169408004587>.

Ntelekos, A.A., Georgakakos, K.P., Krajewski, W.F., 2006. On the uncertainties of flash flood guidance: toward probabilistic forecasting of flash floods. J. Hydrometeorol. 7, 896-915. http://dx.doi.org/10.1175/JHM529.1.

Pilgrim, D.H., Cordery, I., 1992. Flood runoff. In: Maidment, D.R. (Ed.), Handbook of Hydrology. McGraw-Hill, Inc. (chapter 9).

Reed, S., Schaake, J., Zhang, Z., 2007. A distributed hydrologic model and threshold frequency-based method for flash flood forecasting at ungauged locations. J. Hydrol. 337, 402-420. http://dx.doi.org/10.1016/j.jhydrol.2007.02.015, <http:// www.sciencedirect.com/science/article/pii/S0022169407000923>.

Robbez-Masson, J., Mazzoni, C., Vallejo, S., Ernesty, D., Falipou, P., 2002. A regional multimedia soil and landscape database on the web in order to help use and teaching of soil data. In: 17th World Congress of Soil Science, Bangkok, Thailand, pp. 14-21.

Roux, H., Labat, D., Garambois, P.A., Maubourguet, M.M., Chorda, J., Dartus, D., 2011 A physically-based parsimonious hydrological model for flash floods in mediterranean catchments. Nat. Hazards Earth Syst. Sci. 11, 2567-2582. http://dx.doi.org/10.5194/nhess-11-2567-2011, <http://www.nat-hazardsearth-syst-sci.net/11/2567/2011/>.

Schmidt, J.A., Anderson, A., Paul, J., 2007. Spatially-variable, physically-derived flash flood guidance. In: AMS 21st Conference on Hydrology, San Antonio, TX B.

Sweeney, T.L., 1992. Modernized Areal Flash Flood Guidance. Technical Report. NOAA. NWS HYDRO 44, Hydrologic Research Laboratory, National Weather Service, NOAA, Silver Spring, MD. 21pp. (and an appendix).

Tabary, P., 2007. The new French operational radar rainfall product. Part $\mathrm{i}$ : Methodology. Weather Forecast., 22 http://dx.doi.org/10.1175/WAF1004.1.

Tramblay, Y., Bouvier, C., Martin, C., Didon-Lescot, J.F., Todorovik, D., Domergue, J. M., 2010. Assessment of initial soil moisture conditions for event-based rainfall-runoff modelling. J. Hydrol. 387, 176-187. http://dx.doi.org/10.1016/j. jhydrol.2010.04.006, <http://www.sciencedirect.com/science/article/pii/ S0022169410001873>.

Zoccatelli, D., Borga, M., Zanon, F., Antonescu, B., Stancalie, G., 2010. Which rainfall spatial information for flash flood response modelling? A numerical investigation based on data from the Carpathian range, Romania. J. Hydrol. 394, 148-161. http://dx.doi.org/10.1016/j.jhydrol.2010.07.019, Flash Floods: Observations and Analysis of Hydrometeorological Controls. <http:/ www.sciencedirect.com/science/article/pii/S0022169410004440>.

Zoccatelli, D., Borga, M., Viglione, A., Chirico, G.B., Blöschl, G., 2011. Spatial moments of catchment rainfall: rainfall spatial organisation, basin morphology, and flood response. Hydrol. Earth Syst. Sci. 15, 3767-3783. http://dx.doi.org/10.5194 hess-15-3767-2011, <http://www.hydrol-earth-syst-sci.net/15/3767/2011/>. 